\title{
W służbie edukacji kobiet. Działalność Felicji Boberskiej z Wasilewskich (1825-1889)
}

\author{
In the Service of Education of Women. \\ Activity of Felicja Boberska \\ née Wasilewska (1825-1889)
}

\begin{abstract}
ABSTRAKT
Głównym celem artykułu jest ukazanie treści dotyczqcych wychowania i kształcenia kobiet, jakie proponowała w swym pisarstwie Felicja Boberska, wychowawczyni kobiet oraz literatka, Iwowianka z urodzenia. Zajmuje ona zaszczytne miejsce wśród kobiet zasłużonych dla życia naukowego, oświatowego i kulturalnego drugiej połowy XIX wieku. Odnotowano wówczas wzmożonq aktywność kobiet w kwestii starań o równouprawnienie w dostępie do edukacji. Boberska była nie tylko publicystkq i pedagogiem, ale także prowadziła we Lwowie nowoczesna pensie, akływnie uczestniczyła we Iwowskim życiu społecznym i literackim jako działaczka Towarzystwa Pedagogicznego, starsza nauczycielka w żeńskim seminarium nauczycielskim, współpracowniczka Stowarzyszenia Nauczycielek i Iwowskiego Stowarzyszenia pracy kobiet. Była też autorka prac o charakterze pedagogicznym, historycznym, literackim. Całemu jej życiu przyświecała idea poświęcenia i pożytecznej pracy dla innych.
\end{abstract}

Articles and dissertations
SLOWA KLUCZOWE nauczycielka, edukacja kobiet, piśmiennictwo pedagogiczne, myśl pedagogiczna.

KEYWORDS

teacher, education of women, pedagogical writing, pedagogical thought

SPI Vol. 19,2016/3

ISSN 2450-5358

e-ISSN 2450-5366

DOI: 10.12775/SPI.2016.3.006

Artykuły i rozprawy 
Analizujq̨c życie i działalność pedagogicznq Boberskiej, trzeba szczególnie wyróżnić dwa aspekty jej aktywności na rzecz edukacji kobiet, a więc pracę zawodowa i wysiłek włożony w wychowanie i wykształcenie pokolenia polskich kobiet oraz piśmiennictwo, ze szczególnym uwzględnieniem ukazywania przez niq roli kobiet w życiu naukowym, oświatowym, politycznym. Ponadto w tekście zwrócono uwage na pewien wzorzec wizerunku kobiety końca XIX wieku, który propagowała ta nauczycielka i publicystka pedagogiczna.

\section{ABSTRACT}

The main goal of this work is to show the content concerning upbringing and education of women proposed in her writing by a columnist and a teacher Felicja Boberska, educator of women and writer, born in Lviv. She takes up a distinguished position among women meritorious for the scientific, educational and cultural life of the second half of the $19^{\text {th }}$ century. Increased activity of women in the scope of efforts for equality in access to education was noted. Boberska was not only a writer and pedagogue but also ran a modern school for girls, actively participated in social and literary life of Lviv as a member of Pedagogical Society, senior teacher in the women's teacher's college, cooperator of Women Teachers Association and Lviv Women's Work Association. She was also an author of pedagogical, historical and literary works. Throughout her life she was guided by the idea of sacrifice and work for others.

While analysing the life and pedagogical work of Boberska two aspects of her activity for education of women should be especially noted, these are professional work and effort put into the education of a generation of Polish women and her writing with special focus on presentation of the role of women in scientific, educational and political life. Moreover the work points to a certain pattern in the image of a woman of the end of the $19^{\text {th }}$ century that was propagated by this pedagogic writer.

\section{Uwagi wstępne}

Służba na rzecz edukacji kobiet była udziałem wielu nauczycielek, działaczek oświatowych, wychowawczyń młodego pokolenia Polek, a zarazem publicystek i redaktorek. Zasługują one na szczególną uwagę ze względu na wkład, jaki wniosły do dyskusji m. in. na temat 
równouprawnienia kobiet $\mathrm{w}$ dziedzinie edukacji czy form organizacyjnych, postulatów dotyczących instytucji kształcenia. Wprawdzie niektóre doczekały się opracowań w postaci biografii i analizy twórczości, to jednak w dotychczasowym piśmiennictwie na temat udziału kobiet w kulturze drugiej połowy XIX i początków XX wieku nie podjęto się jeszcze charakterystyki życia i twórczości wielu z nich. Trzeba jednak zaznaczyć, że zaobserwować można coraz większe zainteresowanie działalnością pedagogiczną Polek. Świadczą o tym choćby prace autorskie i zbiorowe podejmujące problematykę kształcenia nauczycieli, w których omawia się zasługi na rzecz edukacji kobiet wielu z nich (m.in. w pracach Andrzeja Meissnera). Pojawiaja się także tam, gdzie mowa o ich dążeniach $\mathrm{w}$ dziedzinie edukacji na szczeblu wyższym (np. w pracach Jana Hulewicza). Osobnych opracowań doczekały się m.in. Klementyna z Tańskich Hoffmanowa, Kazimiera Bujwidowa, Jadwiga Petrażycka-Tomicka, Anastazja Dzieduszycka ${ }^{1}$.

$1 \quad$ K. Dormus, Kazimiera Bujwidowa 1867-1932. Życie i dziatalnośćspoteczno-oświatowa, Kraków 2002; R. Dutkowa, Żeńskie gimnazja Krakowa w procesie emancypacji kobiet (1896-1918), Kraków 1995; A. Bilewicz., Prywatne średnie ogólnoksztatcace szkolnictwo żeńskie w Galicji w latach 1867-1914, Wrocław 1998; A. Meissner, Prywatne seminaria nauczycielskie żeńskie w Galicji doby autonomicznej 1896-1914. Powstanie, dziatalność i kadra nauczycielska, w: Nauczyciele galicyjscy, red. A. Meissner, Galicja i jej dziedzictwo, T. 6, Rzeszów 1996; Tenże, Spór o duszę polskiego nauczyciela. Spoteczeństwo galicyjskie wobec problemów ksztatcenia nauczycieli, Galicja i jej dziedzictwo, T. 11, Rzeszów 1999; Tenże, Ksztatcenie nauczycieli w środkowej Galicji 1871-1918, Rzeszów 1974; K. Mrozowska, Sto lat dziatalności kobiet polskich w oświacie i nauce, Kraków 1971; J.E. Dąbrowska, Klementyna. Rzecz o Klementynie z Tańskich Hoffmanowej, Białystok 2008; Kobieta i kultura: kobiety wśród twórców kultury intelektualnej $i$ artystycznej w dobie rozbiorów i w niepodlegtym państwie polskim: zbiór studiów, red. A. Żarnowska i A. Szwarc, Warszawa 1996; Kobieta i edukacja na ziemiach polskich w XIX i XX wieku, red. A. Żarnowska, A. Szwarc, cz. I i II, Warszawa 1995; I. Kosmowska, D. Milkuszyc, A. Szycówna, Kobieta polska jako autorka pedagogiczna, Warszawa 1912; O kobietach: studia i szkice: wiek XIX i XX, pod red. J. Hoff, Rzeszów 2011; Partnerka, matka, opiekunka. Status kobiety w dziejach nowożytnych od XVI do XX wieku, red. K. Jakubiak, Bydgoszcz 2000; A. Habat, Jadwiga Petrażycka-Tomicka. Życie i dziatalność, Rzeszów 2001; J. Falkowska, Przeciw marzycielstwu. Dziatalność edukacyjna Anastazji z Jetowickich Dzieduszyckiej (1842-1890), Toruń 2014; Rola i miejsce kobiet w edukacji i kulturze polskiej, red. W. Jamrożek i D. Żołądź-Strzelczyk, t. II, Poznań 2001; J. Suchmiel, Udziat kobiet w nauce do 1939 roku w Uniwersytecie Jagiellońskim, Częstochowa 1994. 
Nadal jednak jest spora grupa zasłużonych, nieco niedocenionych Polek, np. Zofia Kowerska, Antonina Machczyńska, czy Felicja Boberska z Wasilewskich. Choć niektórym z nich poświęcono artykuły $\mathrm{w}$ pracach zbiorowych czy hasła $\mathrm{w}$ opracowaniach słownikowych, to ciągle brak syntetycznego ujęcia ich działalności i analizy najważniejszych dzieł poświęconych sprawom oświaty i wychowania.

\section{Wpływ rodziny na zainteresowania społeczno-oświatowe Felicii Boberskiej}

Całemu jej życiu przyświecała idea poświęcenia i pożytecznej pracy dla innych. Felicja Boberska z domu Wasilewska, wychowawczyni kobiet oraz literatka, lwowianka $z$ urodzenia, zajmuje zaszczytne miejsce wśród kobiet zasłużonych dla życia naukowego, oświatowego i kulturalnego drugiej połowy XIX wieku. Byłą nie tylko publicystką i pedagogiem - w latach 1845-1864 opiekowała się więźniami politycznymi, brała udział w działalności konspiracyjnej; w latach 1853-1884 (z przerwą 1864-1867 spowodowaną represjami popowstaniowymi) prowadziła we Lwowie nowoczesną pensję; aktywnie uczestniczyła we lwowskim życiu społecznym i literackim; była autorką prac o charakterze pedagogicznym, historycznym, literackim. Dała się poznać jako działaczka Towarzystwa Pedagogicznego we Lwowie ${ }^{2}$, starsza nauczycielka w żeńskim seminarium nauczycielskim, współpracowniczka Stowarzyszenia Nauczycielek i lwowskiego Stowarzyszenia Pracy Kobiet ${ }^{3}$.

Podejmując zasygnalizowany w tytule problem, trzeba wziąć pod uwagę dwa aspekty jej działalności na rzecz edukacji kobiet, a więc uczestnictwo we lwowskim życiu społecznym i kulturalnym (pracę

2 F. Boberska wygłaszała liczne odczyty w Towarzystwie Pedagogicznym, jako jedna z jego działaczek. Patrz A. Meissner, Spór o duszę polskiego nauczyciela. Spoteczeństwo galicyjskie wobec problemów ksztatcenia nauczycieli, dz. cyt., s. 146-147; S. Wasylewski, Boberska z Wasilewskich Felicja 1825-1889), w: Polski Stownik Biograficzny, T. II, Kraków 1936, s. 149-150; R. Terlecki, Osiwiata dorostych i popularyzacja nauki w Galicji w okresie autonomii, Wrocław-Warszawa-Kraków-Gdańsk-Łódź 1990; B. Czajecka, Z domu w szeroki świat. Droga kobiet do niezależności w zaborze austriackim w latach 1890-1914, Kraków 1990;

3 A. Meissner, Spór o duszę polskiego nauczyciela. Spoteczeństwo galicyjskie wobec problemów ksztatcenia nauczycieli, dz. cyt., s. 146-147. 
zawodową i wysiłek włożony w wychowanie i wykształcenie pokolenia polskich kobiet - w Towarzystwie Pedagogicznym, Stowarzyszeniu Nauczycielek, a także w zakładzie kształcenia kobiet i lwowskim seminarium nauczycielskim żeńskim) oraz piśmiennictwo, ze szczególnym uwzględnieniem ukazywania przez nią roli kobiet w życiu naukowym, oświatowym, politycznym. Służbę na rzecz edukacji kobiet należy także rozumieć jako przygotowanie i wydanie drukiem takich ważnych prac, jak np. Historia literatury polskiej ofiarowana mtodym uczacym się Polkom i innych dzieł ukazujących i upamiętniających kulturę narodową.

Podstawę źródłową niezbędną do opracowania tytułowego problemu stanowiły trzy grupy materiałów. Mam na myśli zbiory zgromadzone w Zakładzie Narodowym im. Ossolińskich we Wrocławiu, a przede wszystkim korespondencję Felicji Boberskiej (m.in. listy od Tadeusza Wasilewskiego, Tadeusza Romanowicza, Marii Ilnickiej) ${ }^{4}$ oraz jej pisma z dziedziny historii, historii literatury i historii oświaty, a także opracowania jej poświęcone (np. w Polskim Słowniku Biograficznym).

Felicję Boberską bez wątpienia ukształtowała atmosfera domu rodzinnego. Byłą córką Tadeusza Wasilewskiego i Antoniny z Radwańskich. Jej rodzice prowadzili dom otwarty dla ówczesnej inteligencji, ludzi kultury, ale i polityki. Wystarczy choćby wspomnieć bywających tam: Wacława Zalewskiego, Agenora Gołuchowskiego, ks. Leona Sapiehę, Karola Szajnochę, Aleksandra Fredrę i Wincentego Pola. Było to zatem miejsce skupiające ludzi zatroskanych o dobro i przyszłość narodu. Jak podają źródła, gospodarze, jak i goście, przywiązywali uwagę do atmosfery tych spotkań, do swobody wypowiedzi oraz do należnej tematom dyskusji powagi. Można więc stwierdzić, że w takiej atmosferze wyrosła także Boberska. Mając za przykład ojca, wywiązywała się ze swoich obowiązków z pełną odpowiedzialnością, ale i pogodą ducha, serdecznością i łagodnością dla otaczających ją ludzi. Potwierdzeniem głębokiej relacji i przywiązania

$4 \quad$ Zakład Narodowy im. Ossolińskich, Rkps 6825/II, Papiery Tadeusza Romanowicza; Rkps 7902/II Pisma Felicji z Wasilewskich Boberskiej; Rkps 5918/II Korespondencja Henryka Schimitta; Rkps 6205/II Korespondencja Wojciecha Kętrzyńskiego; Rkps 8049/I Korespondencja Józefa Kajetana i Pauliny Janowskich; Rkps 7187/II Papiery Bolesława i Marii Wysłouchów; Rkps 5157/II Listy do Felicji Boberskiej od Redakcji „Dziennika Mód“. 
do ojca mogą być listy, które zgromadzone są w zborach Zakładu Narodowego im. Ossolińskich we Wrocławiu 5 .

Felicja Boberska swoje zamiłowanie do pracy wychowawczej, ale i pedagogiczne zdolności objawiała już jako dziecko (jedno z dziesięciorga dzieci państwa Boberskich). Warto wspomnieć, że byłą pomocą matce w codziennych obowiązkach. Już wówczas zdradzała swoje zainteresowania opowiadając młodszym historie biblijne, dzieje Polski, ucząc je śpiewu, krzewiąc miłość do ojczyzny. W wieku lat trzynastu gromadziła wokół siebie dzieci z sąsiedztwa i przygotowywała dla nich wykłady, których te z zaciekawieniem słuchały ${ }^{6}$. Sama nauki pobierała od nauczycielki Ludwiki Zbyszewskiej, także od ojca, natomiast geografii uczył ją Wincenty Pol, a historię, literaturę, estetykę i filozofię studiowała pod kierunkiem długoletniego redaktora „Dziennika literackiego” oraz „Gazety Narodowej”, Jana Dobrzańskiego?

\section{Aktywność pedagogiczna i oświatowa Felicji Boberskiej}

Początkowo swoje pedagogiczne zamiłowania realizowała będąc wykładowczynią historii starożytnej i polskiej dla sześciu panien, we Lwowie w 1843 roku. Sytuacja rodzinna skłoniła ją do dawania płatnych lekcji, a także podjęcia pracy zarobkowej. Dokonywała wówczas przekładów dzieł obcych autorów, np. szwedzkiej pisarki Fredriki Bremer, akcentującej dążenia emancypacyjne kobiet ${ }^{8}$.

Wreszcie w 1853 roku otworzyła zakład wychowania kobiet, który kształcił dziewczęta przez niemal trzydzieści lat. Rok później odbył się tam pierwszy publiczny egzamin, a dzięki jej staraniom, dwa lata po rozpoczęciu funkcjonowania tej placówki, uzyskała ona tzw. zatwierdzenie rządowe i cieszyła się dużym uznaniem w środowisku

5 Zakład Narodowy im. Ossolińskich, Rkps 4363/II Listy Tadeusza Wasilewskiego.

6 Pisma Felicji z Wasilewskich Boberskiej, Lwów 1893, s. VIII.

7 Tamże.

8 Fredrika Bremer (1801-1865), pisarka szwedzka. Prekursorka realizmu w literaturze Szwecji, autorka powieści i opowiadań społeczno-obyczajowych, dotyczących głównie problemu emancypacji kobiet, m.in.: Nina (1835, wydanie polskie 1855), Sąsiedzi (1837, wydanie polskie 1852). W dużym stopniu poprzez swoje utwory (na przykład powieść pt. Hertha z 1856) zaznaczyła wysiłki emancypacyjne kobiet tamtych czasów. 
lwowskim. Także sama inicjatorka przedsięwzięcia stała się czołową postacią w kulturze Lwowa9 . O tym miejscu mówiło się, że był to zakład naukowy dla dziewcząt znany każdemu zarówno we Lwowie, jak i w całym kraju, kogo żywo obchodzily sprawy narodowe, oraz jak stwierdził Juliusz Starkel „(...) i w kim serce polskie gorętszym biło tętnem"10. Z pewnością było tak za sprawą jego kierowniczki. We wspomnieniach tych, którzy mieli możliwość się z nią zetknąć, dominują takie określenia, jak: równowaga ducha, niewymuszona skromność, dobro, naturalność w kontaktach z ludźmi. Nie dziwi więc fakt, że lgnęły do niej uczennice lwowskiej pensji. Wychowanki Boberskiej, także i po ukończeniu nauki, podejmując swoje życiowe wyzwania odnosiły się do niej z szacunkiem i przywiązaniem.

Pensja Boberskiej była miejscem, gdzie pracowano nad podnoszeniem poziomu moralnego i umysłowego kobiet lwowskich. Nie bez znaczenia była także propagowana przez nią idea krzewienia uczuć patriotycznych. Przykładem tych starań może być jej zaangażowanie w powstanie tajnego związku tzw. Klaudynek, na cześć patronki Klaudyny Potockiej, którego członkinie ślubowały oddanie ojczyźnie ${ }^{11}$. Związek ten postawił sobie za cel rozbudzanie i podnoszenie ducha narodowego wśród ludu wiejskiego. Posiadał swój statut oraz własną modlitwę za ojczyznę. Jak podają źródła: „Dziecinne to stowarzyszenie, wkrótce dość rozgałęzione, stało się w 63 roku zawiązkiem organizacji niewieściej w Galicji, tak czynnej i zasłużonej w sprawie powstania"12. Natomiast wybuch powstania styczniowego przyczynił się do wyłonienia się z tej organizacji „Komitetu Niewiast Polskich” pod przewodnictwem Boberskiej. W efekcie inicjatorkę aresztowano i odebrano na trzy lata przywilej edukowania młodych kobiet, a zakład kształcenia zamknięto. Czasu tego jednak Boberska nie zmarnowała, bowiem wtedy powstało jej dzieło Historia literatury polskiej ofiarowana mtodym, uczacym się Polkom.

9 S. Wasylewski, Boberska z Wasilewskich Felicja 1825-1889), dz. cyt., s. 149-150 .

10 J. Starkel, Panna Felicja, „Kronika Powszechna“ 1912, nr 42, s. 264.

11 Klaudynki - stwarzyszenie powołane przez Zofię Romanowiczównę, Wandę Dybowską, Julią Dzierżanowską i F. Boberską, mające na celu budzenie uczuć patriotycznych, samokształcenie, szerzenie czytelnictwa, znajomości historii i rodzimych tradycji.

12 Pisma Felicji z Wasilewskich Boberskiej, dz. cyt., s. XIV. 
Jej aktywność zawodowa to także praca w charakterze starszej nauczycielki $\mathrm{w}$ żeńskim seminarium nauczycielskim we Lwowie. W myśl rozporządzenia ministerialnego, 26 maja 1871 roku placów$\mathrm{ka}$ ta rozpoczęła swoje funkcjonowanie, a stanowisko dyrektora objął wówczas Antoni Łuczkiewicz ${ }^{13}$. I chociaż Boberska pracowała krótko, ze względu na konieczność godzenia obowiązków kierowniczki zakładu i nauczycielki seminarium, także i tam została zapamiętana jako: (...) przełożona znanego chlubnie w całym kraju zakładu wychowawczego, kobieta rozległej i gruntownej nauki, wychowawczyni kilku pokoleń zacnych matek i autorka wielu prac pedagogicznych i literackich, znana i szanowna w całym kraju" ${ }^{14}$. Nie mogąc przeznaczyć na pracę w seminarium wymaganej liczby godzin, poświęciła się swojej macierzystej placówce. Jednak wypada zauważyć, że oba te zakłady wychowania i kształcenia realizowały program bogaty w naukę języka ojczystego, literaturę polską, naukę dziejów, które były szczególnie w tym okresie „skarbem w rękach nauczyciela i potężnym środkiem do wszechstronnego oddziaływania na uczennice"15.

Jaki zatem styl nauczania preferowała $\mathrm{w}$ swojej praktyce? W odpowiedzi na to pytanie można stwierdzić, że miała ona swoje charakterystyczne metody i zasady nauczania. Uczennice nie otrzymywały od swojej nauczycielki podręczników. Preferowała metodę podającą, a więc wykład materiału z danej dziedziny. Niektóre z nich były następnie dyktowane w całości, do innych podopieczne otrzymywały notatki. W taki sposób Boberska uczyła historii, literatury polskiej, literatury klasycznej i powszechnej, estetyki oraz pedagogii. Mając na względzie jakość powyższych zajęć, przygotowywała się do nich bardzo starannie: „(...) czytając wiele, robiąc rozliczne notatki, a dopiero po wszechstronnym rozpatrzeniu przedmiotu i przetrawieniu go w sobie, pisała, i to co napisane, jeszcze czasem kilkakrotnie nawet przerabiając" ${ }^{16}$.Jej wpływ na uczennice trudno przecenić. Przyczyniła się zapewne do rozbudzenia uczuć patriotycznych młodego

13 C.K. Seminaria nauczycielskie męskie i żeńskie Królestwa Galicji i Wielkiego Księstwa Krakowskiego w okresie 1871-1896. Pamiętnik, wydany z powodu ćwierćwiekowego jubileuszu galicyjskich seminariów nauczycielskich, obchodzonego we Lwowie w dniach 19, 20 i 21 listopada 1896 r., Lwów 1896, s. 60.

14 Tamże.

15 Tamże, s. 108-119.

16 Pisma Felicji z Wasilewskich Boberskiej, dz. cyt., s. XII. 
pokolenia kobiet. Jej szczerość w sposobie bycia, siła jej przekonań, zamiłowanie do czynienia dobra stanowity najlepszy dla nich przykład. Służyła swoim wychowankom opieką, ale i radą pozostając z nimi w kontakcie korespondencyjnym.

Trzeba także wspomnieć, że jej ulubionym przedmiotem wykładowym była historia Polski. Jeśli chodzi o literaturę i autorów, z których czerpała przygotowując się do swoich zajęć, należy wspomnieć Lelewela, Moraczewskiego, Mickiewicza i Pola. Do dorobku Mickiewicza odnosiła się ze szczególnym szacunkiem, z uwagi na jego wielką miłość ojczyzny. Już jako dziesięcioletnie dziecko recytowała długie fragmenty „Pana Tadeusza”. Do najbardziej cenionych przez nią twórców należała również Klementyna z Tańskich Hoffmanowa, której poświęciła jeden ze swych odczytów ${ }^{17}$. Była zdania, że to jej właśnie zawdzięczamy zmianę kierunku w wychowaniu, a więc wyzbywanie się w nim lekkomyślności, powierzchowności oraz tego, co cudzoziemskie $^{18}$. Ponadto zauważyła, iż to Hoffmanowa sprawiła, że kobiety polskie pokochały wszystko co dobre i szlachetne, zapragnęly „światła i wiedzy”. Warto wspomnieć, że Panna Felicja, jak ją nazywano, w swej pracy zawodowej zabiegała także o równouprawnienie przyrodoznawstwa $z$ literaturą, historią i sztukami pięknymi, co nie zawsze spotykało się ze zrozumieniem.

Zasługą jej była też atmosfera zakładu kształcenia kobiet. Sama Boberska jako przełożona zakładu potrafiła docenić sumienną, rzetelną pracę. Drobne ułomności i chwilowe braki nauczycielek, które tam uczyły, zwykle znajdowały wyrozumiałość i wsparcie ze strony kierowniczki.

Mówiąc o niej i jej działalności w służbie edukacji kobiet można zauważyć, że zdecydowanie walczyła z kastowością szlachecką. Toteż uczennice zakładu rekrutowały się z różnych warstw społecznych. Pochodziły ze środowisk wiejskich, ale naukę pobierały także dzieci mieszczańskie. Wszystkim natomiast starała się wpoić idee prawdziwie chrześcijańskiej demokracji, które sama wyniosła z domu rodzinnego. Niosło to za sobą oczywiście pewne konsekwencje. Jej wychowanki, obeznane $\mathrm{z}$ literaturą i historią Polski, pragnęły większego

17 Tamże; F. Boberska, Klementyna z Tańskich Hoffmanowa, Odczyt Felicji Boberskiej, Lwów 1871.

18 Tamże. 
swego udziału w życiu społecznym, współdziałania na równi z mężczyznami na polu wychowania narodowego czy innych sfer, zamiast pozostać jedynie gospodynią, żona i matką. Jak wiadomo, nie zawsze taka ich postawa czy dążenia spotykały się z akceptacją i uznaniem. Dodać także należy, że przez szereg lat Boberska organizowała wykłady, których audytorium stanowiły zarówno byłe uczennice, jak $\mathrm{i}$ inne zainteresowane tematyką panie.

Szacunek i uznanie środowiska zaskarbiła sobie również jako inspiratorka tzw. niedziel w salonie literackim Boberskiej, a więc spotkań, które przede wszystkim miały na celu propagowanie piśmiennictwa polskiego, zwłaszcza dorobku Juliusza Słowackiego. Bywały tam znakomitości ówczesnego środowiska, ludzie nauki, kultury, oraz młodzież pasjonująca się literaturą. Częstymi gośćmi salonu byli: polski historyk, przedstawiciel lelewelowskiej szkoły historycznej Henryk Szmitt, polski pisarz i dziennikarz pochodzenia ormiańskiego Jan Zacharyasiewicz, polski poeta, publicysta społeczny, nazywany często „ostatnim wielkim poetą romantyzmu” Kornel Ujejski, członek organizacji narodowej w Galicji, jeden z dowódców oddziałów powstania styczniowego i literat Tadeusz Romanowicz, polski pisarz, publicysta, działacz społeczny, związany z Towarzystwem Gimnastycznym „Sokól” we Lwowie Juliusz Starkel i inni. Także i to grono zapamiętało udzielającą się serdeczną, ożywczą atmosferę, poczucie, że wszyscy uczestnicy, każdy według swoich sił i zdolności, są „pracownikami na niwie ojczystej"19. Dyskutowano o sprawach kraju, także o nowościach wydawniczych, wybitnych twórcach literackich, o oświacie ludu, przyszłości Polski.

Spotkania te zapisały się w pamięci ich uczestników jako chwile niezwykłego ożywienia w Galicji, a także rozbudzenia nadziei narodowych. Nadawały ton środowisku literackiemu i dziennikarskiemu, a wkrótce także i sprawom natury politycznej.

$\mathrm{Z}$ przeglądu jej aktywności wynika, że była ona inspiratorką wielu działań na rzecz oświaty kobiet oraz krzewienia i podtrzymywania patriotycznego ducha. Cieszyło ją rozbudzające się na nawo życie narodowe, przywileje uzyskane w wyniku autonomii, a zwłaszcza wprowadzenie języka polskiego jako wykładowego do szkół. Interesowała się także polityką, obradami sejmu. Zachęcała swoje uczennice do

19 Pisma Felicji z Wasilerwskich Boberskiej, dz. cyt., s. XV. 
przyczyniania się, choćby najmniejszą pracą swoją i wysiłkiem, do odrodzenia się ojczyzny. Ta działaczka Towarzystwa Pedagogicznego we Lwowie, wspólpracowniczka Stowarzyszenia Nauczycielek oraz lwowskiego Stowarzyszenia pracy kobiet, dała się poznać jako niestrudzona bojowniczka o sprawy narodu.

\section{Piśmiennictwo Feliçi z Wasilewskich Boberskiej- kierunki i problematyka}

Mówiąc o piśmiennictwie Felicji Boberskiej i jego znaczeniu dla edukacji kobiet, trzeba wskazać na ważne pojawiające się w nim kierunki. Przede wszystkim ukazywała w nim niełatwą rolę kobiety w życiu naukowym, oświatowym, kulturalnym i politycznym. Sporą część swojego pisarstwa poświęciła zasłużonym dla narodu - kobietom i mężom stanu. Ważnym wątkiem, który podejmowała, była sprawa wychowania i kształcenia kobiet - stąd też jej prace powstałe z myślą o młodych, uczących się Polkach. Trzeba również podkreślić, że autorka łączyła historię, historię literatury oraz historię oświaty i wychowania.

Pierwszy kierunek - biografistykę historyczną - reprezentują publikacje poświęcone postaciom, które w szczególny sposób zapisały się na kartach historii polskiej. Należą do nich: Klaudyna Potocka, Emilia Sczaniecka, Klementyna z Tańskich Hoffmanowa, Emilia Plater, Maria Pruszyńska, Maria Raszanowiczówna, Antonina Tomaszewska, Wilhelmina Kasprowiczówna, Kunegunda z Platerów księżna Ogińska. Autorka w pracy pt. O Polkach, które się szczególniej zastużyty Ojczyźnie w powstaniu listopadowym wydarzenia listopadowe traktowała jako objawy godności i życia narodu, a także ogromne poświęcenie dla ojczyzny ${ }^{20}$. Kobiety polskie, o których pisała, w jej ocenie spełniły swą powinność, a także wskazały drogę młodszym pokoleniom. Pozostawily wzory cnót oraz prawdziwego patriotyzmu i stąd należy im się pamięć. Autorka tego stwierdzenia ubolewała, że często mówiąc lub pisząc o podniosłych wydarzeniach $\mathrm{z}$ historii Polski oddaje się cześć tylko mężczyznom, a przecież „(...) niewiasty polskie nie mniej także spełniły swą powinność, nie mniej zasłuży się

20 F. Boberska, O Polkach, które się szczególniej zastużyty Ojczyźnie w powstaniu listopadowym, Lwów 1893. 
Ojczyźnie i rodakom"21. Podkreślała, że to kobieta-matka rozbudzała i zaszczepiała w sercach swoich dzieci miłość do ojczyzny. Przypisywała im także cechy szczególne, odrębne wśród innych kobiet świata. Mawiała, że są związane od narodzin z powinnością chrześcijańską, obowiązkami domowymi, oddane niewieścim pracom, chociaż zbyt mało jeszcze wykształcone, często ciche i skromne. Jednak kobiety te, w chwilach największej potrzeby, potrafią zdobyć się na niespotykaną dzielność ducha. Powołując się na słowa Mickiewicza pokazywała, że Polka swoją pozycję zdobyła nie dzięki teoretycznym rozprawom o równouprawnieniu płci, ale dzięki swej działalności i ofierze.

Jak już wcześniej wspomniano, szczególnym uznaniem i szacunkiem Boberska otaczała Klementynę z Tańskich Hoffmanową, jej dorobek i rolę, którą odegrała w dziejach edukacji kobiet. Poświęciła jej odczyt wygłoszony we Lwowie w 1871 roku $^{22}$. Prezentowała w nim stanowisko, że wciąż warto mówić i pisać o jej zasługach dla „kilku pokoleń niewieścich”23. Zaznaczała, że pisma Hoffmanowej wpłynęły na ulepszenie wychowania kobiet w ogóle, a także były bodźcem ku zwróceniu go na tory narodowe. Można też stwierdzić, że zachwyt Boberskiej dla Klementyny wynikał także stąd, że obie autorki propagowały w życiu, pracy i wychowaniu niemal identyczne wartości. Należy do nich miłość bliźnich, postawa patriotyczna, praca na rzecz rodziny, troska o to, by być coraz lepszą, światlejszą obywatelką. W opinii Boberskiej, Hoffmanowa była kolejną Polką, która przysłużyła się ojczyźnie znakomitym charakterem i własną, wytrwałą pracą.

$Z$ podobną estymą odnosiła się do Narcyzy Żmichowskiej ${ }^{24}$. Wymieniała ją jako jedną z tych kobiet, które odznaczyły się niewieścimi cnotami, zarówno domowymi, jak i obywatelskimi. Uznawała jej poetyckie zdolności, służbę dla ojczyzny, dobre, godne i pracowite życie. Doceniała pracę na rzecz Towarzystwa demokratycznego, działalność w kręgu patriotów (z Moraczewskim, Libeltem, Szczaniecką). Wspominała ją jako gorliwą nauczycielkę wywierającą zbawienny wpływ na swoje uczennice. Podobnie jak Boberska, pragnęła ona dla

21 Tamże, s. 1.

22 F. Boberska, Klementyna z Tańskich Hoffmanowa, dz. cyt.

23 Tamże, s. 1.

24 F. Boberska, Narcyza Żmichowska, Lwów 1893. 
kobiet wiedzy, udziału w pracy i poświęcenia. Chwaliła ją za głos rozsądku w sprawach równouprawnienia, stwierdzając: „Żąda więc wykształcenia zastosowanego do właściwości niewieściego umysłu, a nie współudziału kobiety w każdym męskim zawodzie (...)"25. Żmichowska imponowała jej sposobem ujmowania rodzinnych obowiązków, dorobkiem literackim, charakterystycznym dla niej sposobem i stylem wypowiadania się na ważne, dotyczące narodu sprawy.

Pisarstwo Boberskiej dotyczyło także zasłużonych dla narodu: literatów, poetów, działaczy politycznych, mężów stanu. W poczet tych postaci wpisuje się Karol Balińskii ${ }^{26}$, polski poeta, członek radykalnych grup narodowowyzwoleńczych, np. Stowarzyszenia Ludu Polskiego, nieco niedoceniony patriota i poeta Henryk Jabłoński ${ }^{27}$, zasłużeni dla narodu Tadeusz Kościuszko i Jan Kiliński ${ }^{28}$, historyk, bibliograf i działacz polityczny Joachim Lelewel ${ }^{29}$, poeta i bojownik o sprawy narodu Mieczysław Romanowski ${ }^{30}$, narodowy wieszcz Adam Mickiewicz ${ }^{31}$, a także król Zygmunt August ${ }^{32}$. Taki wybór bohaterów dla swoich odczytów w Towarzystwie Pedagogicznym jest nieprzypadkowy, bowiem swoim życiem, dokonaniami w dziedzinie literatury, kultury, polityki, wyznawanymi wartościami i zasługami dla Polski i Polaków dali oni dowód troski o przyszłość następnych pokoleń. Taka postawa, jak już wspomniano, była bliska sercu Boberskiej. Stąd potrzeba uwiecznienia ich dorobku, ocalenia od zapomnienia, a tym samym chęć ukazywania tak ważnych, w niespokojnych czasach wzorów postaw.

Kolejny kierunek w piśmiennictwie Boberskiej to wychowanie i kształcenie kobiet. Wychowywać i kształcić autorka chciała przybliżając polskie piśmiennictwo i wskazując w nim najważniejsze wartości. Nurt ten reprezentują przede wszystkim dwie prace jej autorstwa:

25 Tamże, s. 13.

26 F. Boberska, Karol Baliński, Odczyt Felicji Boberskiej, Odbitka z „Reformy”, Kraków 1882

27 F. Boberska, Henryk Jabtoński, Odbitka z „Nowej Reformy”, Kraków 1883.

28 F. Boberska, Kościuszko i Kiliński, Lwów 1893.

29 F. Boberska, Joachim Lelewel, Lwów 1893.

30 F. Boberska, Mieczystaw Romanowski, Lwów 1893.

31 F. Boberska, Adam Mickiewicz, Lwów 1893.

32 F. Boberska, Zygmunt August i jego czasy w Polsce, Lwów 1884. 
Historia literatury polskiej ofiarowana mtodym, uczacym sie Polkom ${ }^{33}$ oraz O ksztatceniu charakteru: odczyt dla kobiet miany na rzecz Towarzystwa Pedagogicznego we Lwowie dnia 23 lutego 1881 roku ${ }^{34}$. Antoni Małecki nazwał autorkę tych prac „ideałem mistrzyni i wzorem, za którym iść powinny wszystkie polskie nauczycielki” ${ }^{35}$. Jakie więc przesłanie, jakie wartości płyną z tych prac? Daje się w nich zauważyć pewną tęsknotę za tradycją, za wartościami pielęgnowanymi dawniej, a w czasach współczesnych autorce nieco zapomnianych. Jest to także zapis obserwacji autorki na temat tego, że często człowiek w obliczu wyzwania, w tym przypadku pracy dla ojczyzny i bliźnich, nie potrafi zdobyć się na działanie, wysiłki i wyrzeczenia. Może właśnie dlatego literaturę nazywała kierowniczką narodu, w której tkwi jego siła. Często wyprzedza ważne fakty, będąc niejako prorokiem przyszłości narodu. Z kolei dzieje literatury traktowała jako dopełnienie historii narodu, jego obrazu duchowego, życia, myśli i uczuć. W przekonaniu Boberskiej, znajomość literatury daje człowiekowi narzędzia do samodoskonalenia, świadomość tego kim jest i wiedzę o tym, czego oczekuje od niego społeczeństwo, jaka ma być jego rola. Pisała: „W literaturze, w każdej dziejów epoce, składa naród zarody i miarę swych sil”'36. Wykład historii literatury polskiej autorka podzieliła na sześć okresów, począwszy od kształcenia się narodu pod wpływem chrześcijaństwa i łaciny do 1400 roku, poprzez powstanie i działalność Akademii Krakowskiej, złoty okres literatury polskiej w XVI-XVII wieku, następnie epokę nazwaną przez autorkę „Szkoły w Polsce”. Publikację zamyka przegląd prozy i piśmiennictwa religijnego. Dla każdego okresu Boberska nakreśliła zarys ogólny epoki, scharakteryzowała sprawy oświaty i wychowania, jej najważniejszych autorów, a także próbki poezji i prozy. Znajdujemy tam wzmianki o teatrze, pieśniach, sztukach, wiadomości z historii, geografii,

33 F. Boberska, Historia literatury polskiej ofiarowana mtodym, uczacym się Polkom T. 1, Lwów 1870. Warto dodać, że historia literatury jest połączeniem historii oraz historii wychowania.

34 F. Boberska, O ksztatceniu charakteru: odczyt dla kobiet miany na rzecz Towarzystwa Pedagogicznego we Lwowie dnia 23 lutego 1881 r., Lwów 1881.

35 S. Wasylewski, Boberska z Wasilewskich Felicja 1825-1889), dz. cyt., s. 150. Antoni Małecki, historyk literatury, mediewista i językoznawca, rektor Uniwersytetu Lwowskiego.

36 F. Boberska, Historia literatury polskiej, dz. cyt., s. 1. 
teologii, prawa kanonicznego, nauk matematycznych i przyrodniczych. Przywracała pamięć o zasłużonych dla rodzimej literatury i kultury twórcach, ukazując dorobek nie tylko znanych i cenionych autorów, np. Jana Kochanowskiego, Mikołaja Reja czy Mikołaja Sępa-Szarzyńskiego, ale i wielu innych, jak to określiła „poetów mniejszej wartości”. Stwierdzała, że jeśli chodzi o naukę, to Polacy z racji swojej sytuacji politycznej, kontroli zaborcy itp. mają jeszcze wiele do nadrobienia. Jednak podkreślała, że w oświacie, literaturze i poezji polscy twórcy wyprzedzają inne narody. Stąd w swoim piśmiennictwie przywoływała historię rodzimego szkolnictwa, pomniki języka polskiego, a także zasługi tych, którzy zapisali się na kartach historii.

Jeśli chodzi o obecność zachodniej myśli pedagogicznej w jej pracach, to należy wspomnieć o tym, że poświęciła uwagę zasadom pedagogicznym Johna Locke'a, rozpatrując jego koncepcje pod względem kształtowania charakteru ${ }^{37}$. Odnosiła się także do dorobku Jana Henryka Pestalozziego, przybliżając jego zasługi na rzecz wychowania najbardziej potrzebujących warstw społeczeństwa, nazywając go dobroczyńcą ludzkości ${ }^{38}$.

Z kolei system wychowania Felicji z Wasilewskich Boberskiej, który prezentowała $\mathrm{w}$ swoich pracach, podbudowany był pragnieniem zaszczepiania w wychowankach miłości do Boga, ojczyzny i ludzkości. Można stwierdzić, że była ona gorącą propagatorką miłości ojczyzny wbrew zakazom i podejrzliwości władz szkolnych. Potwierdzenie tej tezy odnaleźć można bez trudu na kartach jej prac. Zapraszana przez Towarzystwo Pedagogiczne, wygłaszała odczyty publiczne w lwowskiej sali ratuszowej, które gromadziły wielu słuchaczy ${ }^{39}$. Jednym z takich wystąpień było to z 1881 roku pt. O ksztatceniu charakteru.

Zasygnalizowany w tytule odczytu problem miał być celem i efektem wszelkich zabiegów wychowawczych. Cel ten określany był przez Boberską także jako kształcenie wytrwałej woli. Natomiast największym i najważniejszym zadaniem wychowawcy w tym procesie

37 F. Boberska, Zasady pedagogiczne Lockego pod względem kszttcenia charakteru, Odczyt z dnia 3. kwietnia 1878, w: Pisma Felicji z Wasilewskich Boberskiej, dz. cyt., s. 396-412.

38 F. Boberska, Jan Henryk Pestalozzi, w: Pisma Felicji z Wasilerwskich Boberskiej, dz. cyt., s. 413-438.

39 F. Boberska, Historia literatury polskiej, dz. cyt., s. 1. 
miało być kształtowanie silnego charakteru, który byłby gotowy do poświęceń i ofiar. Podkreślała, że każda nauka, każdy zabieg wychowawcy nie może opierać się jedynie na własnym doświadczeniu czy przekonaniu. Potrzeba tu jeszcze wiedzy z dziedziny psychologii, która jest doskonałym narzędziem poznawczym w tym procesie. Obok powyższych zaleceń, wskazywała na wagę wychowania fizycznego, indywidualnego podejścia do każdego wychowanka, jak również znaczenie nauki moralnej. Tylko wówczas możliwe jest wykształcenie charakteru, a więc w opinii Boberskiej: „(...) woli odważnej, niezłomnej, a szlachetnej i prawej, to wierność sumieniu i powinności, zacnym przeświadczeniom i zasadom, prawda w czynie i słowie (...)"40. Dodawała także, że tylko ludzie z charakterem swoją posługą pomnażali tak dobro ojczyzny, jak i ludzkości.

Trzeba jednak zauważyć, że pomimo tych wzniosłych i trudnych zarazem celów, w dążeniu do ich urzeczywistnienia sama autorka posługiwała się jedynie łagodnością i cierpliwością. Jak wskazują na to wspomnienia wychowanki Boberskiej: „Gdy jej przyszło upomnieć, lub zganić uczennicę - głos jej drżał, świadcząc o tym, że więcej może kosztowało ją udzielenie nagany, niż przyjęcie jej przez uczennicę (...)" "41. Bez wątpienia jednak można powiedzieć, że w ocenie tych, którzy z nią wspólpracowali, czerpali od niej naukę, byli obserwatorami jej życia i pracy zawodowej, Boberska była uosobieniem tych szlachetnych cech, które sama ceniła u innych.

\section{Uwagi końcowe}

Podsumowując dokonania Felicji Boberskiej na rzecz edukacji kobiet, daje się zauważyć kilka wyraźnych obszarów i form. Od najmłodszych lat żywo interesowały ją sprawy wychowania i związane z tym procesem możliwości, a więc przekazywanie uczennicom określonych wartości, propagowanie wśród nich pożądanych postaw. Okazją do praktyki w tym obszarze były początkowo prywatne lekcje, a następnie kierownictwo i życzliwa opieka w zakładzie wychowania kobiet. Spełniając swoje życiowe ambicje, Boberska działała również $\mathrm{w}$ strukturach stowarzyszeń, propagując tam postawę pa-

40 F. Boberska, O ksztatceniu charakteru, dz. cyt., s. 8.

41 Tamże, s. 265. 
triotyczną, chrześcijańską, obywatelską. Dowodem jej zapatrywań na sprawy wychowania i edukacji kobiet są prace, w których podejmowała temat niełatwej roli kobiety w życiu naukowym, oświatowym, kulturalnym i politycznym. Była jednak przekonana o tym, że propagując określony typ charakteru: gorliwej nauczycielki, dobrej matki, rzetelnej działaczki, mądrej pisarki można osiągnąć wiele nie tylko wśród uczennic lwowskiego zakładu, ale także trafić do szerszej rzeszy polskich kobiet z konkretnym przesłaniem.

Doceniając pracę Boberskiej na rzecz edukacji i wychowania Polek, jej uczennice po śmierci mistrzyni ufundowały pomnik w kościele oo. Karmelitów we Lwowie oraz doprowadziły do wydania zbioru jej pism pt. Pisma Felicji z Wasilewskich Boberskiej, które ukazały się we Lwowie w 1893 roku². Chcąc uczcić jej pamięć, z pomocą Towarzystwa Szkoły Ludowej założyły bursę dla dziewcząt imienia Boberskiej. Inną inicjatywą, świadczącą o uznaniu dla niej, było utworzenie przez jedną z uczennic „Kółka Polek”, którego zamiarem było przede wszystkim pielęgnowanie narodowego ducha, ale i gromadzenie środków dla potrzebujących.

Bezsprzecznie główną jej zasługą była praca wychowawcza, a więc prowadzenie zakładu, w którym zdziałała nieopisanie wiele dla całego społeczeństwa, oddziałując na młode pokolenie kobiet nie tylko słowem, ale i pięknym przykładem. Zasługi Boberskiej dobrze oddaje cytat, który znalazł się na kartach „Wstępu” poprzedzającego wybór jej prac: „Są na świecie kobiety wyżej jeszcze uzdolnione, genialne, z umysłem twórczym; są takie, których imiona zapisały dzieje, albo historia literatury albo sztuki; są śmiałe pionierki postępu (...) ale Ona, cicha a wytrwała pracownica "w winnicy Pańskiej», Ojczyźnie, ludzkości i ukochanym swoim oddała całe swoje życie, każde słowo i czyn, każde uderzenie serca"43.

42 W gronie autorów tego przedsięwzięcia znalazły się takie osoby, jak: Zygmuntowa Riegerowa, Władysławowa Riegerowa, Kamilla Kosińska, Marya Gostyńska, Róża Totkowa, Stefania Wechslerowa, Wiktoryja Niedziałkowska, Helena Szemelowska, Zofia Romanowiczówna, Anna Lewicka, Kamilla Poh, Józef Żuliński, Teofil Merunowicz, Juliusz Starkel. Patrz Pisma Felicji z Wasilewskich Boberskiej, dz. cyt.

${ }^{43}$ Pisma Felicji z Wasilerwskich Boberskiej, dz. cyt., s. 1. 


\section{BIBLIOGRAFIA}

Bilewicz A., Prywatne średnie ogólnoksztatcace szkolnictwo żeńskie w Galicji w latach 1867-1914, Wydawnictwo UniwersytetuWrocławskiego, Wrocław 1998.

Boberska F., Klementyna z Tańskich Hoffmanowa, Odczyt Felicji Boberskiej, J. Dobrzański \& K. Groman, Lwów 1871.

Boberska F., O Polkach, które się szczególniej zastużyty Ojczyźnie w powstaniu listopadowym, Wydawnictwo Fundacji im. ś.p. Felicji z Wasilewskich Boberskiej, Lwów 1893.

Boberska F., Narcyza Żmichorwska, Wydawnictwo Fundacji im. ś.p. Felicji z Wasilewskich Boberskiej, Lwów 1893.

Boberska F., Karol Baliński, Odczyt Felicji Boberskiej, Odbitka z „Reformy”, Kraków 1882.

Boberska F., Henryk Jabtoński, Odbitka z „Nowej Reformy”, Kraków 1883.

Boberska F., Kościuszko i Kilinski, Gubrynowicz i Schimdt, Lwów 1893.

Boberska F., Joachim Lelewel, Gubrynowicz i Schimdt, Lwów 1893.

Boberska F., Mieczystaw Romanowski, Gubrynowicz i Schimdt, Lwów 1893.

Boberska F., Zygmunt August i jego czasy w Polsce, K. Łukaszewicz, Lwów 1884.

Boberska F., Historia literatury polskiej ofiarowana mtodym, uczacym się Polkom, T. 1, K. Wild, Lwów 1870.

Boberska F., O ksztatceniu charakteru: odczyt dla kobiet miany na rzecz Towarzystwa Pedagogicznego we Lwowie dnia 23 lutego 1881 r., Księgarnia Polska, Lwów 1881.

C.K. Seminaria nauczycielskie męskie $i$ żeńskie Królestwa Galicji i Wielkiego Księstwa Krakowskiego w okresie 1871-1896, nakł. Dyrekcyj C.K. Seminaryów Nauczycielskich Galicyjskich.

Czajecka B., Z domu w szeroki świat. Droga kobiet do niezależności w zaborze austriackim w latach 1890-1914, Tow. Autorów i Wydawców Prac Nauk. Universitas. Kraków 1990.

Dąbrowska J. E., Klementyna. Rzecz o Klementynie z Tańskich Hoffmanowej, Wydawnictwo Uniwersytetu w Białymstoku, Białystok 2008.

Dormus K., Kazimiera Bujwidowa 1867-1932. Życie i dziatalnoś́ spoteczno-ośriatowa, Secesja, Kraków 2002.

Dutkowa R., Żenskie gimnazja Krakowa w procesie emancypacji kobiet (18961918), Księgarnia Akademicka, Kraków 1995.

Falkowska J., Przeciw marzycielstwu. Dziatalność edukacyjna Anastazji z Jetowickich Dzieduszyckiej (1842-1890), Wydawnictwo Naukowe Uniwersytetu Mikołaja Kopernika, Torun 2014.

Habat A., Jadwiga Petrażycka-Tomicka. Życie i dziatalność, Wydawnictwo Wyższej Szkoły Pedagogicznej, Rzeszów 2001.

Kobieta i kultura: kobiety wśród twórców kultury intelektualnej i artystycznej $w$ dobie rozbiorów $i$ w niepodlegtym państwie polskim: zbiór studiów, red. A. Żarnowska i A. Szwarc, Wydawnictwo DiG, Warszawa 1996. 
Kobieta i edukacja na ziemiach polskich w XIX i XX wieku, red. A. Żarnowska, A. Szwarca, cz. I i II, Wydawnictwo DiG, Warszawa 1995.

Kosmowska I., Milkuszyc D., Szycówna A., Kobieta polska jako autorka pedagogiczna, Wydawnictwo Sekcji pedagogiczno-oświatowej projektowanej Wystawy pracy kobiety polskiej, Warszawa 1912.

O kobietach: studia i szkice: wiek XIX $i$ XX, red. J. Hoff, Uniwersytet Rzeszowski, Rzeszów 2011.

Meissner A., Prywatne seminaria nauczycielskie żeńskie w Galicji doby autonomicznej 1896-1914. Powstanie, dziatalność i kadra nauczycielska, w: Nauczyciele galicyjscy, red. A. Meissner, Galicja i jej dziedzictwo, T. 6, Wydawnictwo Wyższej Szkoły Pedagogicznej, Rzeszów 1996.

Meissner A., Spór o duszę polskiego nauczyciela. Spoteczeństwo galicyjskie wobec problemów ksztatcenia nauczycieli, Galicja i jej dziedzictwo, T. 11, Wydawnictwo Wyższej Szkoły Pedagogicznej, Rzeszów 1999.

Meissner A., Ksztatcenie nauczycieli w środkowej Galicji 1871-1918, Wyższa Szkoła Pedagogiczna, Rzeszów 1974

Mrozowska K., Sto lat dziatalności kobiet polskich w oświacie $i$ nauce, Państwowe Wydawnictwo Naukowe, Kraków 1971.

Pamiętnik, wydany z powodu ćwierćwiekowego jubileuszu galicyjskich seminariów nauczycielskich, obchodzonego we Lwowie w dniach 19, 20 i 21 listopada 1896 r., nakł. Dyrekcyj C.K. Seminaryów Nauczycielskich Galicyjskich, Lwów 1896.

Partnerka, matka, opiekunka. Status kobiety w dziejach nowożytnych od XVI do $X X$ wieku, red. K. Jakubiak, Wydawnictwo Wyższej Szkoły Pedagogicznej, Bydgoszcz 2000.

Pisma Felicji z Wasilewskich Boberskiej, Piller i Spółka, Lwów 1893.

Rola $i$ miejsce kobiet w edukacji i kulturze polskiej, red. W. Jamrożek i D. Żołądź-Strzelczyk, t. II, Wydawnictwo Instytutu Historii Uniwersytetu Adama Mickiewicza, Poznań 2001.

Starkel J., Panna Felicja, „Kronika Powszechna” 1912, nr 42.

Suchmiel J., Udziat kobiet w nauce do 1939 roku w Uniwersytecie Jagiellońskim, Wydawnictwo Wyższej Szkoły Pedagogicznej w Częstochowie, Częstochowa 1994.

Terlecki R., Oświata dorostych i popularyzacja nauki w Galicji w okresie autonomii, Zakład Narodowy im. Ossolińskich, Wrocław-Warszawa-Kraków-Gdańsk-Łódź 1990.

Wasylewski S., Boberska z Wasilewskich Felicja 1825-1889), w: Polski Stownik Biograficzny, T. II, Polska Akademia Umiejętności, Kraków 1936, s. $149-150$.

Zakład Narodowy im. Ossolińskich, Rkps 6825/II, Papiery Tadeusza Romanowicza.

Zakład Narodowy im. Ossolińskich, Rkps 7902/II Pisma Felicji z Wasilewskich Boberskiej.

Zakład Narodowy im. Ossolińskich, Rkps 5918/II Korespondencja Henryka Schimitta. 
Zakład Narodowy im. Ossolińskich, Rkps 6205/II Korespondencja Wojciecha Kętrzyńskiego.

Zakład Narodowy im. Ossolińskich, Rkps 8049/I Korespondencja Józefa Kajetana i Pauliny Janowskich.

Zakład Narodowy im. Ossolińskich, Rkps 7187/II Papiery Bolesława i Marii Wysłouchów.

Zakład Narodowy im. Ossolińskich, Rkps 5157/II Listy do Felicji Boberskiej od Redakcji „Dziennika Mód”.

Zakład Narodowy im. Ossolińskich, Rkps 4363/II Listy Tadeusza Wasilewskiego.

\section{ADRES DO KORESPONDENCJI}

Dr Joanna Falkowska

Uniwersytet Mikołaja Kopernika

Wydział Nauk o Wychowaniu

Katedra Historii Myśli Pedagogicznej

jfal@umk.pl 